\title{
HNF-4- $\alpha$-mutáció okozta monogénes diabetes mellitus (MODY-1) első hazai esete
}

\author{
Jermendy György dr. ${ }^{1}$ - Balogh István dr. ${ }^{2}$ - Gaál Zsolt dr. ${ }^{3}$ \\ ${ }^{1}$ Bajcsy-Zsilinszky Kórház, III. Belgyógyászati Oktató Osztály, Budapest \\ ${ }^{2}$ Debreceni Egyetem, Laboratóriumi Medicina Intézet, Klinikai Genetikai Tanszék, Debrecen \\ ${ }^{3}$ Szabolcs-Szatmár-Bereg Megyei Kórházak és Egyetemi Oktatókórház, \\ Jósa András Egyetemi Oktatókórház, IV. Belgyógyászati Osztály, Nyíregyháza
}

\begin{abstract}
A serdülő- és fiatal felnőttkorban kezdődő diabetes mellitus klasszifikációja néha nehéz. A monogénes diabetesforma felismerése az érintett betegek számára döntő jelentőségű lehet az életminőség, a prognózis és a megfelelő kezelés kiválasztása terén. A MODY (maturity-onset diabetes of the young) alcsoporton belül a MODY-1 elófordulása ritka, a nemzetközi szakirodalom szerint 2000-ig mindössze 13 családot, 2013-ig összesen 173 családot (103 különböző mutációval) azonosítottak világszerte. A szerzők a HNF-4- $\alpha$ gén korábban már leírt mutációján alapuló monogénes diabetesforma (MODY-1) első hazai esetét ismertetik. A 42 éves nőbeteg diabetestörténete 20 éves korában gestatiós diabetesszel indult (csak diétát tartott), majd 26 éves korában tüdőgyulladás kapcsán észlelt hyperglykaemia miatt inzulinterápiát kezdtek. A 20 éves leánya diabetesét 13 éves korában állapították meg, kezdetben 2 -es típusú diabetest véleményeztek (csak diétát tartott), majd 14 éves korában a diabetestípust revideálva ( 1 -es típusú diabetest megállapítva) inzulinterápiát kezdtek. A diabetesmanifesztáció körülményei, a feltúnően alacsony inzulindózis, a halmozott családi diabetes-előfordulás vetette fel a monogénes diabetes gyanúját. Mind az anyánál, mind leányánál molekuláris biológiai módszerrel igazolni lehetett a HNF-4- $\alpha$ gén mutációját (c.869G>A, p.R290H), ennek alapján a MODY-1 diabetes-kórforma kórisméjét. Mindkét beteg esetében az inzulinterápiát szulfanilureakezeléssel lehetett felváltani, ez a terápia az egyéves követés során kifogástalan anyagcserehelyzetet biztosított. A család elérhető tagjainál végzett szưrővizsgálat nem igazolta az indexbetegeknél talált génmutáció további előfordulását. Orv. Hetil., 2016, 157(12), $469-473$.
\end{abstract}

Kulcsszavak: diabetes mellitus, monogénes diabetes, MODY (maturity-onset of diabetes in the young), MODY-1, szulfanilureaterápia

\section{Monogenic form of diabetes mellitus due to HNF4 $\alpha$ mutation (MODY-1) - the first case in Hungary}

The classification of diabetes mellitus in adolescents and young adults is often difficult. The diagnosis of the monogenic form of diabetes may have substantial influence on quality of life, prognosis and the choice of the appropriate treatment of affected patients. Among MODY (maturity-onset of diabetes in the young) MODY-1 is rarely detected, only 13 families were described in 2000, and 103 different mutations in 173 families were known in 2013 worldwide. The authors present the first Hungarian case of a monogenic form of diabetes due to HNF4 $\alpha$ mutation (MODY-1). The diabetes of the index patient No. 1 (42-year-old woman with insulin treated diabetes) was diagnosed as gestational diabetes at age of 20 when she was treated with diet only. Later, insulin treatment has been initiated when marked hyperglycaemia was detected during an episode of acute pneumonia at age of 26 . The diabetes of the index patient No. 2 (20-year-old daughter of the index patient No. 1, treated also with insulin) was diagnosed as type 2 diabetes at age of 13 and the patient was treated with diet only. Later the classification was modified to type 1 and insulin therapy was initiated at age of 14 . The manifestation of diabetes, the familial occurrence and the low dose insulin requirement were suggestive for monogenic diabetes. Using molecular genetic method a mutation $(\mathrm{c} .869 \mathrm{G}>\mathrm{A}$, p.R290H) of HNF4 $\alpha$ gene was found and MODY-l was diagnosed in both cases. Insulin therapy was switched to treatment with low dose sulfanylurea and an excellent glycaemic control was achieved and sustained at follow-up of l-year. No further positive cases were found during screening of other family members. 
Keywords: diabetes mellitus, monogenic diabetes, MODY (maturity-onset of diabetes in the young), MODY-1, sulfanylurea treatment

Jermendy, Gy., Balogh, I., Gaál, Zs. [Monogenic form of diabetes mellitus due to HNF4 $\alpha$ mutation (MODY-1) - the first case in Hungary]. Orv. Hetil., 2016, 157(12), 469-473.

(Beérkezett: 2016. január 19.; elfogadva: 2016. február 4.)

\section{Rövidítések}

GCK gén = glükokináz gén; HGMD = Human Gene Mutation Database; HNF = (hepatocyte nuclear factor) hepatocyta nukleáris faktor; $\mathrm{MODY}=$ maturity-onset diabetes of the young; $\mathrm{PCR}=($ polymerase chain reaction $)$ polimeráz láncreakció

A diabetes mellitus szindrómán belül az egy gén egy vagy több defektusára visszavezethető monogénes diabetesformák felismerése, a kórisme molekuláris biológiai bizonyítása, az érintettek kezelése a diabetológia egyik új kihívását jelenti napjainkban [1]. Általános vélekedés szerint a cukorbeteg-populáción belül a monogénes kórformák a nem inzulinnal kezelt esetek 1-2\%-át teszik ki Európában [2]. Noha a molekuláris biológiai bizonyítás lehetősége egyre inkább elérhető, mégis valószínü, hogy a monogénes diabetesformák mind felnőtt-, mind gyermekkorban aluldiagnosztizáltak $[3,4]$. Ennek oka az, hogy a monogénes formák gyakran differenciáldiagnosztikai kérdéseket vetnek fel, különösen a fiatal felnőttkorban felismert diabetesesetekben, amikor is néha nehézséget jelent az l-es típusú diabetes elhúzódó formájától (latent autoimmune diabetes in adults - LADA), illetve a 2-es típusú diabetes szokatlan formában történő manifesztációjától való elkülönítés. Az is előfordul azonban, hogy az első észlelő orvos figyelmét elkerülik azok a gyanújelek (például családi halmozódás, feltûnően alacsony inzulinigény), amelyek alapján a monogénes diabetes lehetőségére gondolni lehetne.

A monogénes diabetes mellitus előfordulására közel öt évtizeddel ezelőtt Fajans és Conn, majd Tattersall hívták fel a figyelmet [5-7]. A MODY (maturity-onset diabetes of the young) elnevezést Tattersall és Fajans 1975-ben használta először [7]. A szerzők a MODY-t akkor kizárólag a klinikum alapján karakterizálták, s jellemzőnek tartották a korai (25. életév előtti) kezdetet, az inzulinkezelés szükségességének hiányát, ezzel összefüggésben a felismerést követően legalább néhány évig a C-peptid kimutathatóságát és a családi előfordulást (legalább két generációban) $[8,9]$. A genetika fejlődése az utóbbi egykét évtizedben ezen a téren jelentős fejlődést hozott, ma a MODY-n belül már 13 alcsoportot különítünk el, az elnevezés MODY-1-től MODY-13-ig terjed. Ezekben az esetekben a genetikai háttér (mutáció) feltárt. Az irodalom használja a MODY-X fogalmat a családon belül halmozódó azon esetek számára, ahol a genetikai háttér jelenleg nem mutatható ki vagy nem ismert [8-11].
A MODY-esetek felismerése nemcsak elméleti szempontból érdekes, hanem gyakorlati következményei is jelentősek. Az érintettek esetében gyakran hosszú ideig vagy véglegesen abba lehet hagyni a korábban megkezdett inzulinterápiát. A családon belül szưrôvizsgálattal olykor tünetmentes - a betegség magas penetranciája okán - preszimptomatikus állapotú egyéneket lehet azonosítani, e tény ismeretében egy későbbi diabetesmanifesztáció esetén azonnal helyes gyógyszeres terápiát lehet indítani. A családra jellemző génmutáció ismerete indokolja az utódok időben történő molekuláris biológiai vizsgálatát.

A ma érvényes diabetesklasszifikációs rendszerben a monogénes diabetesek az úgynevezett egyéb speciális diabetesformák közé tartoznak. Összességében ma mintegy 50-féle különböző monogénes diabetest ismerünk $[10,12,13]$.

A MODY-alcsoport közös jellemzője, hogy a pancreas béta-sejtjei elégtelen mennyiségű inzulint termelnek, a diabetes kialakulásának patomechanizmusában az inzulinszekréció primer defektusa kap központi szerepet. A MODY-n belül a leggyakoribb a HNF-1- $\alpha$ gén mutációja okozta MODY-3. Ezt követi a gyakoriságban a MODY-2 vagy GCK-MODY (glükokináz-MODY). E két alcsoport együttesen a monogénes diabetesesetek többségét adja $[1,14]$. A GCK-MODY-tól eltekintve a többi gyakoribb MODY eseteiben olyan transzkripciós faktorok mutációjáról van szó, amelyek béta-sejt-diszfunkciót okoznak [15]. A MODY-1 a HNF-4- $\alpha$ gén mutációjának a következménye $[16,17]$. A MODY-1 és a MODY-3 klinikuma hasonló, mindkettőre jellemző a nagyfokú szulfanilureaérzékenység. A MODY-1 előfordulása ritka, 2000-ig mindössze 13 családot azonosítottak világszerte [18]. Ellard és Colclough közlése szerint 2006-ban a HNF-4- $\alpha$ gén 31 mutációja volt ismert 40 családban [19], 2013-ban már 173 családban detektált 103 különböző mutációról számoltak be [20,21]. Jelenleg 112, MODY-1-et okozó mutáció ismert a Humán Gén Mutációs Adatbázis (HGMD, 2015.2) szerint. A viszonylagos ritkaság miatt az egyes eseteket még ma is közlik [22]. Az általunk detektált mutációt a HNF-4- $\alpha$ génben korábban már leírták a nemzetközi irodalomban, jelenleg az első hazai esetet ismertetjük.

\section{Esetismertetés}

A 42 éves nőbeteg (III/6) a 20 éves leányával (IV/3) együtt 2014-ben jelentkezett a Bajcsy-Zsilinszky Kórház 
Diabetes Ambulanciáján a cukorbetegségükkel kapcsolatos gondok miatt, tanácsot kérve a további teendőket illetően.

Az anyánál (született: 1972) vércukor-emelkedést első ízben a terhessége alatt, 1992-ben, majd második terhessége alatt 1994-ben észleltek. Gestatiós diabetest állapítottak meg, a vércukorkontrollhoz csak diéta tartása elegendő volt, egészséges fiút és leányt szült. Később, 1998-ban (26 éves korában) tüdőgyulladás kapcsán találtak magas vércukorértékeket, ekkor inzulinterápiát kezdtek. Diéta tartása mellett az inzulinkezelési rendszer a beteg jelentkezésekor az alábbi volt: NovoRapid délben $2 \mathrm{E}$ (nagyobb étkezés esetén 3-4 E), Levemir penfill este 5-6 E. A testsúly $58 \mathrm{~kg}$, a testmagasság $168 \mathrm{~cm}$ (BMI: $20,5 \mathrm{~kg} / \mathrm{m}^{2}$ ) volt. Panaszt nem említett, fizikális belszervi vizsgálattal eltérést nem lehetett találni. $\mathrm{HbA}_{1 \mathrm{c}}{ }^{-}$ értéke 5,9-6,4\% volt.

Leányánál (született: 1994) 2007-ben (13 éves korában) észlelték először, hogy folyadékigénye megnőtt, a Semmelweis Egyetem Gyermekklinikáján diabetest állapítottak meg. Kezdetben 2 -es típusúnak vélték, a beteg 1 évig csak diétát tartott, 1 év után inzulinkezelést vezettek be. A beteg jelentkezésekor diéta tartása mellett az alábbi inzulinkezelési rendszert tartotta: Humalog reggel $2 \mathrm{E}$, délben maximum $2 \mathrm{E}$ (néha ez kimaradt), este gyors hatású inzulint nem adott magának. Bázisinzulinként Lantust használt (este 6-8 E, de nyári periódusban ezt nem adta). A testsúly $59 \mathrm{~kg}$, a testmagasság $181 \mathrm{~cm}$ (BMI: $18,0 \mathrm{~kg} / \mathrm{m}^{2}$ ) volt. Panaszt nem említett, a fizikális vizsgálat negatív eredményű volt. $\mathrm{HbA}_{1 \mathrm{c}}$-értéke $7,3-$ $7,6 \%$ volt.

A két beteg kórtörténete (a diabetes manifesztációjának körülményei, az alacsony inzulinigény és a családi előfordulás) felvetette annak gyanúját, hogy az adott esetben nem l-es típusú, hanem monogénes diabetesről van szó. Rákérdezve kiderült, hogy a család számos tagjánál diabetes volt ismert (1. ábra), ez a gyanút tovább erősítette. A családfa felvételekor megtudtuk, hogy a III/6 indexbeteg (anya) édesapja (II/8) diabeteses volt, diabetese 36 éves korában kezdődött, nem volt elhízott, betegségét orális antidiabetikummal kezelték. A II. generációnál az apai ágon szereplő 6 testvér közül 5 diabeteses volt, valamennyiüket orális antidiabetikummal kezelték, mindannyian elhunytak, így tôlük vérmintát nyerni nem tudtunk. A III/6 indexbeteg édesanyja (II/9) nem volt diabeteses, a II. generációnál az anyai ágon szereplő 4 testvér közül l volt diabeteses (II/10). $\mathrm{Az}$ I. generáció tagjai között az apai ágon egy diabeteses férfi $(\mathrm{I} / 2)$ szerepelt, ennek a generációnak a tagjai elhunytak.

A két indexbetegtől (III/6 és IV/3) vért vettünk molekuláris biológiai vizsgálat céljára. Alvadásgátolt perifériás vérből történő DNS-izolálás után a HNF-1- $\alpha$ (MODY-3), a GCK gén (MODY-2), illetve a HNF-4- $\alpha$ (MODY-1) gén molekuláris genetikai vizsgálatát végeztük el. A HNF-1- $\alpha$ gén, a GCK gén és a HNF-4- $\alpha$ gén exonjait PCR-módszerrel amplifikáltuk, majd a PCR- termékeket bidirekcionális DNS-szekvenálással vizsgáltuk. A HNF-1- $\alpha$ és a GCK génben a betegséggel kapcsolatba hozható patogén mutációt nem tudtunk detektálni. A HNF-4- $\alpha$ génben a c.869G >A, p.R290H, a szakirodalomban korábban már leírt [19] patogén eltérést igazoltuk, amely alátámasztotta a MODY-1 diagnózisát. A későbbiekben elvégzett családi szűrővizsgálat során már csak a családra jellemző génmutáció esetleges jelenlétét vizsgáltuk.

A molekuláris genetikai lelet ismeretében, a MODY-1 kórisme megállapítását követően mindkét indexbeteg esetében az inzulinterápiát felfüggesztettük, diéta tartása mellett gliclazid adását kezdtük, sikerrel. A terápiaváltás óta egy év telt el, továbbra is jó anyagcserehelyzetet észlelünk, a betegek panaszmentesek. Az anya napi $30 \mathrm{mg}$ gliclazid mellett jó anyagcsere-egyensúlyban van (vércukor-önellenőrzés értékei 5,0-9,0 mmol/1 között, $\mathrm{HbA}_{\mathrm{lc}}$ : 5,8\%, szérum-C-peptid: $1,1 \mathrm{ng} / \mathrm{ml}$ ). Leánya a kezdeti napi $30 \mathrm{mg}$ gliclazidot napi 15-re csökkentette a túl alacsony vércukorértékek miatt, csak stresszesebb időben emeli a dózist napi $30 \mathrm{mg}$-ra. Anyagcserehelyzete szintén jó $\left(\mathrm{HbA}_{\mathrm{lc}} 6,8 \%\right.$, szérum-C-peptid: $\left.1,1 \mathrm{ng} / \mathrm{ml}\right)$.

Időközben megtörtént a család elérhető, genetikai szempontból indokolt, az indexbetegekkel vér szerinti kapcsolatban álló tagjainak szúrővizsgálata. A III/6 indexbeteg testvére (III/3), továbbá másik gyermeke $(\mathrm{IV} / 2)$ esetében a szû́rővizsgálat nem igazolta az ismert mutációt. Az indexbeteg (III/6) unokahúga (IV/l), illetve a harmadik generációhoz tartozó távoli unokatestvére (III/l) szürővizsgálata negatív volt. A felmenők közül egyedül a második generációhoz tartozó II/9 egyént tudtuk vizsgálni (a III/6 indexbeteg anyja, illetve a $\mathrm{IV} / 3$ indexbeteg nagyanyja), de az ismert mutációt nem lehetett igazolni. A szürővizsgálatunk tehát a család elérhető tagjainál egyetlen esetben sem igazolta az indexbetegeknél talált génmutáció további előfordulását.

\section{Megbeszélés}

Esetünk jól példázza a serdülö- és fiatal felnőttkorban kezdődő diabetes mellitus klasszifikációjának nehézségeit. A 42 éves anya kórtörténete 20 éves korban gestatiós diabetesként indult, majd 26 éves korában tüdőgyulladás kapcsán talált magas vércukorértékek miatt inzulinterápiát kezdtek, l-es típusú diabetesnek vélve a diabetestípust. A beteg 16 éven keresztül inzulinterápiában részesült, mielőtt a monogénes diabetes gyanúja felmerült. A 20 éves leányának kórtörténete 13 éves korban indult, 1 évig csak diétát tartott, ekkor 2-es típusú diabetesnek vélték a kórformát, de 1 év után inzulinterápiát kezdtek, feltételezve, hogy mégiscsak l-es típusú diabetesről van szó. A beteg 6 éven keresztül részesült inzulinterápiában, mielőtt látóterünkbe került, s felmerült a monogénes diabetes lehetősége. Monogénes diabetesre a diabetes manifesztációjának körülményei és a családi halmozódás terelte a gyanút, de feltűnő volt az is, hogy mind az anya, mind leánya esetében a több éve tartó in- 


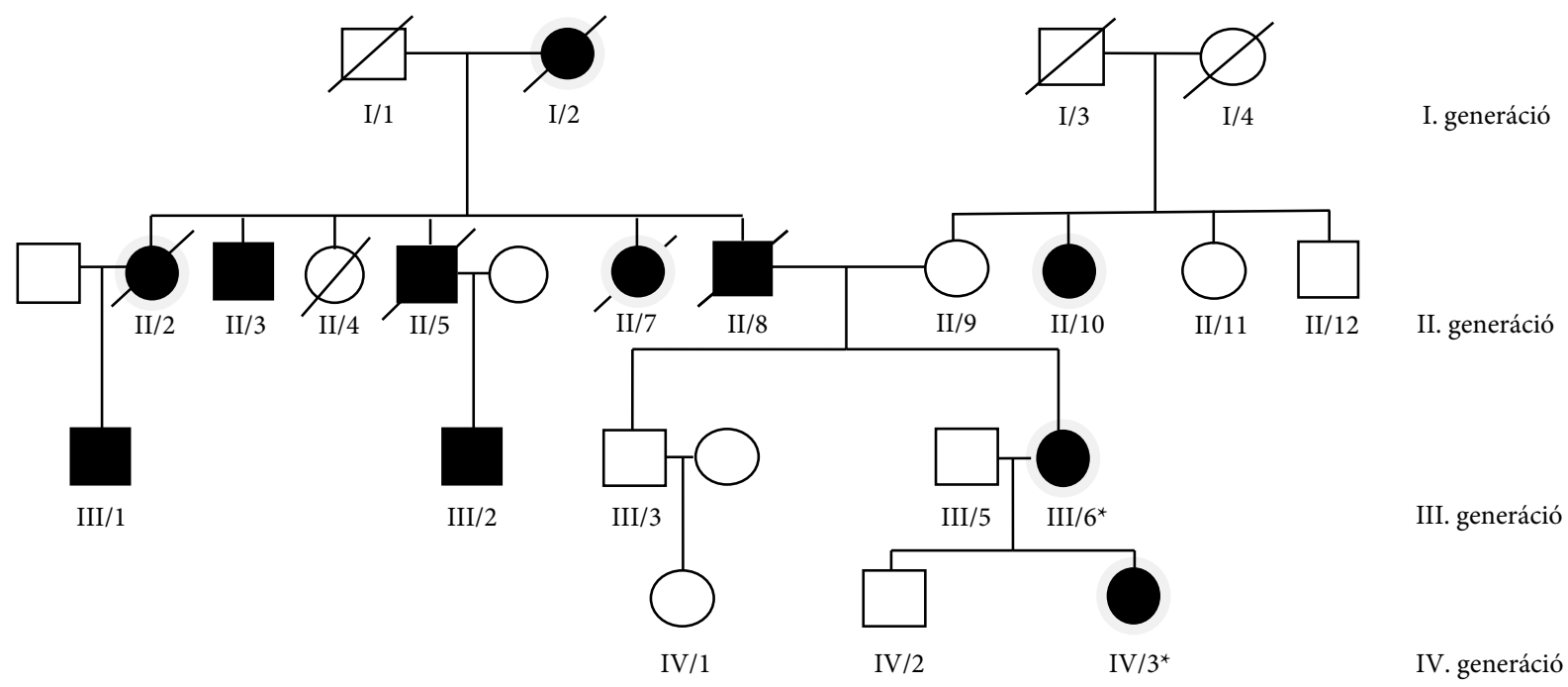

*Indexbetegek (III/6 és IV/3; anya és leánya)

/ szimbólum áthúzva: elhunytak

férfi, cukorbeteg

nő, cukorbeteg

$\square$ férfi, nem cukorbeteg

nő, nem cukorbeteg

1. ábra | A családfa

zulinterápia feltűnően alacsony dózisokkal folyt. Ezek a körülmények megfelelnek a Tattersall és Fajans által évtizedekkel ezelőtt leírt klasszikus, jellemző kórtörténeti adatoknak [7]. Természetesen ma már a monogénes diabetes mellitus korrekt kórisméjéhez hozzátartozik a molekuláris biológiai vizsgálat. Két betegünknél ez megtörtént, s így hazánkban elsőként igazoltuk a HNF-4- $\alpha$ mutációján alapuló MODY-1 kórisméjét.

A családon belül szürővizsgálatot csak korlátozottan tudtunk végezni, mert az I. generáció minden tagja elhunyt, a II. generáció apai ágán szerepelő 6 testvér szintén elhunyt. Nem lehet határozott választ adni arra a kérdésre, hogy a család melyik tagjánál jelent meg először a mutáció. Feltehető, hogy a III/6 indexbeteg (anya) apai felmenői ágán már előfordulhatott a mutáció.

A korrekt diagnózis ismeretében a korábban évekig folytatott inzulinterápiát fel lehetett függeszteni, az elkezdett szulfanilureaterápia (gliclazid) alacsony dózisban hatékonynak bizonyult mindkét indexbeteg esetében. Értelemszerűen ez a terápiaváltás az érintettek életminőségére jelentős hatással volt. Az 1-es típusú diabeteshez viszonyítva ugyanis kedvezőbb távoli prognózist tudtunk felvázolni, bár irodalmi adatok alapján nem lehet azt ígérni számukra, hogy életük végéig inzulinra sohasem lesz szükség [11]. Mindenesetre biztató körülmény az, hogy az egy évre terjedő utánkövetés során a kezdő szulfanilureadózis változatlanul kiváló anyagcserehelyze- tet biztosít. Az egyik indexbeteg (20 éves leány) esetében a korrekt diagnózis segítheti a családtervezést, beleértve azt is, hogy a majdani utódok szúrővizsgálatának jelentőségére már most felhívtuk a figyelmet. Ugyanakkor unokahúga (IV/1) esetleges leszármazottainál - miután a génmutációt nem hordozza - genetikai vizsgálatok elvégzése nem lesz indokolt.

A diabetesgondozás során gyakran erősen leterhelt körülmények között dolgozunk. Ez mégsem adhat felmentést az alól, hogy a cukorbetegek kórelőzményi adatait ne vegyük fel gondosan. Két betegünk első vizsgálata során a monogénes diabetes gyanúja felmerült, a megerősítéséhez a molekuláris biológiai vizsgálat nélkülözhetetlen volt. Újabban az úgynevezett MODY-kalkulátor segítheti a klinikust a MODY-gyanús esetek felismerésében [23, 24]. Jelentős előrelépés, hogy 2009től már hazánkban is lehetőség nyílik a leggyakoribb MODY-formák molekuláris genetikai vizsgálatára. Bár ezek a vizsgálatok jelenleg még viszonylag drágák, mégis költséghatékonyak [25]. Az adott családnál a vizsgálat során a HNF-4- $\alpha$ gén mutációját hazánkban első ízben igazoltuk, ez alapján a MODY-1 kórisméje megállapítható volt, s a két indexbeteg inzulinterápiáját sikerrel váltottuk fel szulfanilureakezeléssel.

Anyagi támogatás: A molekuláris genetikai vizsgálat (B. I.) OTKA-támogatással (K109076) valósult meg. 
Szerzôi munkamegosztás: J. Gy.: Az indexpáciensek vizsgálata, a családi szűrôvizsgálat megszervezése, a közlés ötlete, a kézirat elkészítése. B. I.: A molekuláris genetikai vizsgálatok végzése, az eredmény interpretációja, a kézirat átnézése. G. Zs.: Irodalom gyưjtése, a kézirat átnézése, szövegezése. A kézirat végleges változatát mindhárom szerző elolvasta és jóváhagyta.

Érdekeltségek: A szerzőknek nincsenek érdekeltségeik.

\section{Irodalom}

[1] Gaál, Z., Kántor, I., Somogyi, A., et al.: Clinical and genetic heterogeneity of MODY. [A MODY klinikai és genetikai heterogenitása.] Diabetologia Hungarica, 2003, 11(4), 257-263. [Hungarian]

[2] Ledermann, H. M.: Maturity-onset diabetes of the young (MODY) at least ten times more common in Europe than previously assumed? Diabetologia, 1995, 38(12), 1482.

[3] Malecki, M. T.: The search for undiagnosed MODY patients: what is the next step? Diabetologia, 2010, 53(12), 2465-2467.

[4] Rubio-Cabezas, O., Hattersley, A. T., Njolstad, P. R., et al.: ISPAD Clinical Practice Consensus Guidelines 2014. The diagnosis and management of monogenic diabetes in children and adolescents. Pediatr. Diabetes, 2014, 15(Suppl. 20), 47-64.

[5] Fajans, S. S., Conn, J. W.: Tolbutamide-induced improvement in carbohydrate tolerance in young people with mild diabetes mellitus. Diabetes, 1960, 9(2), 83-88.

[6] Tattersall, R. B.: Mild familial diabetes with dominant inheritance. Q. J. Med., 1974, 43(2), 339-357.

[7] Tattersall, R. B., Fajans, S. S.: A difference between the inheritance of classical juvenile-onset and maturity-onset type diabetes of young people. Diabetes, 1975, 24(1), 44-53.

[8] Fajans, S. S., Bell, G. I., Polonsky, K. S.: Molecular mechanisms and clinical pathophisiology of maturity-onset diabetes of the young. N. Engl. J. Med., 2001, 345(13), 971-980.

[9] Fajans, S. S., Bell, G. I.: MODY - History, genetics, pathophysiology and clinical decision making. Diabetes Care, 2011, 34(8), 1878-1884

[10] Ellard, S., De Franco, E.: Next-generation sequencing for the diagnosis of monogenic diabetes and discovery of novel aetiologies. In: Gloyn, A. L., McCarthy, M. I. (eds.). Genetics in diabetes. Type 2 diabetes and related traits. Frontiers in Diabetes, Vol. 23). Karger, Basel, 2014, 71-86.

[11] Anik, A., Catli, G., Abaci, A., et al.: Maturity-onset diabetes of the young (MODY): an update. J. Pediatr. Endocrinol. Metab., $2015,28(3-4), 251-263$

[12] Jermendy, G. (ed.): Diagnosis of diabetes mellitus, care of diabetic patients in the adulthood. Guideline of the Hungarian Diabetes Association, 2014. [A diabetes mellitus kórismézése, a cukorbetegek kezelése és gondozása felnőttkorban. A Magyar Diabetes Társaság szakmai irányelve, 2014.] Diabetologia Hungarica, 2014, 22(Suppl. 1), 2-84. [Hungarian]
[13] American Diabetes Association: Standards of medical care in dia betes 2016. Diabetes Care, 2016, 39(Suppl. 1), S1-S112.

[14] Gaál, Z., Kántor I., Albert L., et al.: Glucokinase-MODY and gestational diabetes. [Glukokináz-MODY és gestatiós diabetes.] Diabetologia Hungarica, 2006, 14(3), 227-232. [Hungarian]

[15] Yamagata, $K$.: Roles of $\mathrm{HNFl} \alpha$ and $\mathrm{HNF} 4 \alpha$ in pancreatic $\beta$-cells: lessons from a monogenic form of diabetes (MODY). Vitam. Horm., 2014, 95, 407-423.

[16] Yamagata, K., Furuta, H., Oda, N., et al.: Mutations in the hepatocyte nuclear factor-4alpha gene in maturity-onset diabetes of the young (MODY1). Nature 1996, 384(6608), 458-460.

[17] Pearson, E. R., Pruhova, S., Tack, C. J., et al.: Molecular genetics and phenotypic characteristics of MODY caused by hepatocyte nuclear factor 4alpha mutations in a large European collection. Diabetologia, 2005, 48(5), 878-885.

[18] Fajans, S. S., Bell, G. I.: Maturity onset diabetes of the young. a model for genetic studies of diabetes mellitus. In: LeRoith, D., Taylor, S. I., Olefsky, J. M. (eds.): Diabetes mellitus: a fundamental and clinical text. 2nd ed. Lippincott Williams \& Wilkins, Philadelphia, 2000.

[19] Ellard, S., Colclough, K.: Mutations in the genes encoding the transcription factors hepatocyte nuclear factor 1 alpha (HNF1A) and 4 alpha $(H N F 4 A)$ in maturity-onset diabetes of the young. Hum. Mutat., 2006, 27(9), 854-869.

[20] Colclough, K., Bellanne-Chantelot, C., Saint-Martin, C., et al.: Mutations in the genes encoding the transcription factors hepatocyte nuclear factor 1 alpha and 4 alpha in maturity-onset diabetes of the young and hyperinsulinemic hypoglycemia. Hum. Mutat., 2013, 34(5), 669-685.

[21] Colclough, K., Saint-Martin, C., Timsit, J., et al.: Clinical utility gene card for: Maturity-onset diabetes of the young. Eur. J. Hum. Genet., 2014, 22(9). doi: 10.1038/ejhg.2014.14. el-e6

[22] Delvecchio, M., Di Paola, R., Mangiacotti, D., et al.: Clinical heterogeneity of abnormal glucose homeostasis associated with the HNF4A R311H mutation. Ital. J. Pediatr., 2014, 40, 58. doi: 10.1186/1824-7288-40-58

[23] Shields, B. M., McDonald, T. J., Ellard, S., et al.: The development and validation of a clinical prediction model to determine the probability of MODY in patients with young-onset diabetes. Diabetologia, 2012, 55(5), 1265-1272.

[24] Bodnár, A., Gaál, Z., Balogh, I., et al.: The predictive value of the MODY calculator in the prediction of monogenic diabetes forms. [A MODY-kalkulátor értéke a monogénes diabetesformák predictiojában.] Diabetologia Hungarica, 2014, 22(1), 33-38. [Hungarian]

[25] Naylor, R. N., John, P. M., Winn, A. N., et al.: Cost-effectiveness of MODY genetic testing: translating genomic advances into practical health applications. Diabetes Care, 2014, 37(1), 202209.

(Jermendy György dr., Budapest, Maglódi út 89-91., 1106 e-mail: gyjermendy@mail.datanet.hu) 